\title{
PERANAN METODE DISKUSI MENGGUNAKAN MEDIA STIK ES KRIM DALAM MENINGKATKAN MOTIVASI, MINAT DAN HASIL BELAJAR MATEMATIKA KELAS II SEKOLAH DASAR NEGERI SRENGSENG SAWAH 12 PAGI JAKARTA
}

\author{
Suhaemi ${ }^{1}$ \\ Guru SDN Srengseng Sawah 12 Pagi Jakata \\ surel:suhaemi051972@gmail.com \\ Wahyu Bagja Sulfemi ${ }^{2}$ \\ STKIP Muhammadiyah Bogor \\ surel:wahyubagja@gmail.com
}

\begin{abstract}
ABSTRAK
Tujuan utama PTK ini adalah Upaya Meningkatkan Hasil Belajar Peserta Didik Kelas II Sekolah Dasar Negeri Srengseng Sawah 12 Pagi Kota Jakarta Selatan Pada Mata Pelajaran Matematika Tema Penjumlahan Dan Pengurangan Bilangan Sampai 500 Melalui Metode Diskusi Menggunakan Media Stik Es Krim. Penelitian Tindakan Kelas dilaksanakan di SDN Srengseng Sawah 12 Pagi Kecamatan Jagakarsa Kota Jakarta Selatandengan jumlah 31 orang peserta didik (18 laki - laki dan 13 perempuan) kelas II Pada pembelajaran prasiklus dengan menggunakan metode ceramah dan media buku cetak, papan tulis, peserta didik yang tuntas dalam belajar hanya 51\%. Kemudian peneliti lanjutkan pada pembelajaran siklus I dengan menambahkan metode diskusi dan alat peraga jari tangan, peserta didik yang mencapai ketuntasan sebanyak 68\%.Peneliti lanjutkan lagi pada pembelajaran siklus II, peneliti mencoba memperbaiki kekurang pada saat siklus 1 selain menggunakan metode diskusi juga menambahkan media stik es krim.Pada siklus 2 peserta didik yang tuntas dalam belajarnya sebanyak $97 \%$ peserta didik.Dengan demikian penerapan metode dan alat peraga stik es krim telah memberikan pengaruh yang sangat baik dengan meningkatkan hasil belajar dan motivasi peserta didik. Materi yang disampaikan dimengerti peserta didik, tanggung jawab peserta didik terhadap tugas tinggi, serta membantu peserta didik untuk terlibat aktif di dalam kelas.
\end{abstract}

Kata kunci : Hasil Belajar Matematika, Metode Diskusidan Media Stik Es Krim

\section{PENDAHULUAN}

\section{A. Latar Belakang Masalah}

Matematika merupakan salah satu mata pelajaran di sekolah yang sangat berperan penting dalam dunia pendidikan karena matematika dapat meningkatkan pengetahuan peserta didik dalam berpikir secara logis, rasional, kritis, cermat, efektif dan efisien.Matematika juga merupakan bidang ilmu yang mendasari perkembangan teknologi dimana untuk menguasai dan menciptakan teknologi dimasa depan diperlukan penguasaan matematika sejak dini.

Bilangan merupakan salah satu komponen dalam pelajaran matematika yang sangat penting dan mendasar yang harus dipahami setiap peserta didik.Pada materi operasi 
hitung bilangan, peserta didik diharapkan mampu melakukan operasi penjumlahan dan pengurangan. Peserta didik yang menguasai bilangan dengan baik pada akhirnya akanmampu memanfaatkan pengetahuannya tentang bilangan pada berbagai bidang dan berbagai situasi dalam kehidupannya.

Pentingnya peserta didik mempelajari operasi penjumlahan dan pengurangan adalah sebagai modal awal dalam meneruskan tingkat operasi bilangan yang lebih tinggi lagi. Karena matematika merupakan pelajaran yang bersifat hierarki maka setiap sub bab yang ada akan sangat berkaitan dengan sub bab berikutnya. Untuk itu penguasaan operasi penjumlahan dan pengurangan sebagai dasar awal untuk mempelajari materi matematika selanjutnya.

Dalam pengalaman peneliti sebagai pengajar, matematika cenderung di anggap sebagai mata pelajaran yang sulit, membosankan atau kurang menarik. Kondisi nyata yang terjadi sekarang adalah rendahnya hasil belajar matematika tentang operasi penjumlahan dan pengurangan merupakan kendala yang di alami oleh peserta didik kelas 2 SDN Srengseng Sawah 12 Pagi. Pemahaman anak usia sekolah dasar yang masih berada pada tahap operasional konkretmengakibatkan sebagian besar peserta didik kelas 2 SDN Srengseng Sawah 12 Pagi kurang aktif dan tidak mampu berfikir kritis dalam pelajaran matematika materi penjumlahan dan pengurangan bilangan sampai 500. Hasil belajar peserta didik kelas 2 SDN Srengseng Sawah 12 Pagidalam pelajaran matematika materi penjumlahan dan pengurangan bilangan sampai 500 belum mencapai Kriteria Ketuntasan Minimum (KKM) yang harus dicapai yaitu 70.

Pada pembelajaran prasiklus yang peneliti lakukan pada peserta didik kelas 2 SDN Srengseng Sawah 12 pagi, didapat nilai rata - rata kelas 65,00. Peserta didik yang tuntas dalam belajar hanya berjumlah 16 orang dari 31 peserta didik atau 50\% dan yang belum mencapai ketuntasan belajar sebanyak 15 orang dari 31 peserta didik atau $50 \%$. Sedangkan hasil pengamatan menunjukkan bahwa sebanyak 10 orang dari 31 peserta didik menjawab dengan benar atau sebesar 30\%, dan yang belum menjawab dengan benar sebanyak 21 orang dari 31 peserta didik atau dengan kata lain $70 \%$.

Selain itu, situasi dan kondisi peserta didik dalam kelas terlihat banyak peserta didik yang kurang memperhatikan penjelasan guru. Beberapa peserta didik yang asyik mengobrol dengan teman sebangku, sibuk memainkan alat tulis dan ada juga peserta didik yang suka berjalan-jalan di kelas. Ini membuktikan ketidakfokusan peserta didik pada mata pelajaran matematika semakin terlihat. 
Untuk mencapai nilai yang sesuai dengan KKM, guru maupun peserta didik harus melakukan kegiatan pembelajaran dengan baik. Keberhasilan dalam mencapai nilai sesuai KKM merupakan harapan dari semua guru. Ketercapaian KKM ataupun keberhasilan proses pembelajaran bergantung para peran serta atau partisipasi peserta didik di dalam proses pembelajaran dan peran serta dari guru sebagai fasilitator dalam proses pembelajaran.

Dalam pembelajaran matematika dibutuhkan pemahaman konsep yang baik dan benar sebagai dasar untuk pengembangan materi lebih lanjut, hal ini sangat dipengaruhi oleh faktor model pembelajaran yang digunakan. Pembelajaran yang pasif akan menghambat kreatifitas atau pola pikir peserta didik dalam memahami suatu konsep pembelajaran. Oleh karena itu dalam proses pembelajaran matematika peserta didik dituntut benar-benar aktif, sehingga daya ingat peserta didik tentang apa yang telah dipelajari akan lebih baik. Suatu konsep akan mudah dipahami dan diingat oleh peserta didik apabila konsep tersebut disajikan melalui prosedur dan langkah-langkah yang tepat, jelas dan menarik. Keaktifan peserta didik merupakan salah satu faktor yang mempengaruhi keberhasilan dalam belajar.

Rendahnya hasil belajar matematika pada peserta didik kelas 2 SDN Srengseng Sawah 12 pagi dapat di sebabkan penggunaan metode belajar yang kurang sesuai yaitu lebih dominannya aktifitas guru dalam kegiatan belajar mengajar dibandingkan dengan aktivitas peserta didik. Guru hanya memberikan penjelasan materi pembelajaran yang bersifat teoritis, sedangkan peserta didik diminta untuk duduk diam dan mendengarkan penjelasan materi dari guru. Setelah itu, peserta didik di minta untuk mengerjakan soal yang guru tulis di papan tulis maupun mengerjakan soal yang ada di buku latihan. Dengan kata lain, guru kurang membimbing peserta didik untuk membangun pengetahuan, melainkan hanya menirukan dan menghafal apa yang di jelaskan guru sebelumnyaserta mengerjakan soal latihan yang guru minta.

Faktor lainnya adalah penggunaan alat peraga dalam pembelajaran matematika yang tidak konkret, tidak bervariasi, dan tidak menarik dalam menyajikan materi pembelajaran di kelas.Penggunaan media atau alat peraga seperti buku paket, papan tulis, spidol dan jari tanganakan membuat peserta didik jenuh dan menjadi kurang fokus dengan pelajaran. Hal ini tentu saja membuat pembelajaran kurang bermakna bagi peserta didik.

Untuk memperbaiki pembelajaran dan meningkatkan pencapaian hasil pembelajaran yang diharapkan, peneliti merasa perlu melakukan Penelitian Tindakan 
Kelas (PTK).Dengan merefleksi bersama antar guru maka akan teridentifikasi akar permasalahan. Proses pembelajaran yang selama ini hanya didominasi guru, monoton hanya menggunakan metode ceramah diubah menjadi pembelajaran yang menyenangkan bagi peserta didik

Dalam penelitian ini akan diupayakan peningkatan pemahaman peserta didik tentang pelajaran matematika materi penjumlahan dan pengurangan bilangan sampai 500 melalui beberapa siklus yang setiap siklusnya melalui beberapa langkah yaitu mulai dari perencanaan, pelaksanaan, pengamatan atau observasi dan refleksi pembelajaran. Pembelajaran yang menyenangkan dapat dilakukan dengan berbagai model dan penggunaan media pembelajaran yang bervariasi.Akan lebih menyenangkan bila didukung oleh seorang guru yang aktif dan berkompeten.Strategi pembelajaran yang digunakan guru yang aktif itu senantiasa disesuaikan dengan materi pelajaran, proses pembelajaran serta situasi, dan kondisinya, tidak monoton, sehingga tujuan dan hasil pembelajaran dapat dicapai dengan baik.

Berdasarkan uraian diatas, peneliti tertarik untuk melakukan PTK mengenai “Upaya Meningkatkan Hasil Belajar Peserta Didik Kelas 2 Sekolah Dasar Negeri Srengseng Sawah 12 Pagi Pada Mata Pelajaran Matematika Dengan Tema Penjumlahan Dan Pengurangan Bilangan Sampai 500 Melalui Metode Diskusi Menggunakan Media Stik Es Krim."

\section{Identifikasi Masalah}

Dari hasil observasi dan diskusi dengan teman sejawat maka masalah pada Penelitian Tindakan Kelas ini dapat diidentifikasikan sebagai berikut:

a. Rendahnya nilai prestasi belajar Peserta didik yang rata - rata dibawah KKM

b. Sebagian peserta didik kurang memahami penjelasan dari guru tentang pelajaran matematikamateri penjumlahan dan pengurangan bilangan sampai 500.

c. Peserta didik di kelas 2 SDN Srengseng Sawah 12 Pagi cenderung pasif dan kurang tertarik pada materi pembelajaranMatematikamateri penjumlahan dan pengurangan bilangan sampai 500 .

d. Peserta didik tidak mau bertanya ketika diberi kesempatan untuk bertanya.

e. Peserta didik sering tidak fokus di saat guru memberikan materi pelajaran.

\section{Analisa Masalah}

Dari identifikasi masalah, penulis berusaha menganalisa serta merumuskan masalah yang terjadi. Adapun analisa masalah yang ditemukan dalam pembelajaran Matematikamateri penjumlahan dan pengurangan bilangan sampai 500 adalah: 
a. Guru belum menggunakan metodepembelajaran yang sesuai sehingga peserta didik cenderung pasif dalam mengikuti proses pembelajaran.

b. Guru belum menggunakan media pembelajaran yang menarik.

c. Guru kurang memotivasi dan memberikan reward kepada peserta didik dalam proses pembelajaran.

d. Guru tidak melibatkan peserta didik ketika menjelaskan materi.

e. Guru kurang inovatif dalam menyingkapi situasi belajar yang kurang kondusif.

\section{Alternatif dan Prioritas Pemecahan Masalah}

Dari analisis masalah di atas, peneliti menemukan alternatif dan prioritas pemecahan masalah sebagai berikut :

a. Dalam penyampaian pembelajaran guru harus menggunakan metode yang menarik, tepat, mudah dipahami dan memadai agar pembelajaran jadi menyenangkan, metode diskusi kelompok dapat memudahkan pemahaman peserta didik dalam memecahkan masalah dan bisa bertukar pikiran dengan teman sekelompoknya.

b. Guru harus dapat memotivasi dan memberikan reward terhadap seluruh peserta didik

c. Guru harus melibat seluruh peserta didik dalam proses pembelajaran.

d. Guru harus inovatif dalam menyingkapi situasi belajar yang kurang kondusif yang membuat peserta didik bosan dan tidak focus, demonstrasi penggunaan alat peraga dapat mempermudah peserta didik dalam mengerjakan tugas dari guru.

Maka apabila dalam proses kegiatan belajar mengajar khususnya penggunaan metode dan media pembelajaran yang kurang tepat dapat mempengaruhi hasil belajar peserta didik, dalam penelitian tindakan kelas ini, peneliti mencoba meneliti tentang metode diskusi menggunakan media stik es krim untuk meningkatkan pemahaman peserta didik pada mata pelajaran Matematika materi penjumlahan dan pengurangan bilangan sampai 500 di SDN Srengseng Sawah 12 Pagi.

\section{B. Rumusan Masalah}

Berdasarkan latar belakang masalah di atas, maka yang menjadi masalah pokok adalah "Bagaimana meningkatkan hasil belajar peserta didik kelas 2 Sekolah Dasar Negeri Srengseng Sawah 12 Pagi pada mata pelajaran Matematika materi penjumlahan dan pengurangan bilangan sampai 500melalui metode diskusi dan media stik es krim?

\section{Tujuan Penelitian Perbaikan Pembelajaran}


Tujuan utama PTK ini adalah upaya meningkatkan hasil belajar peserta didik kelas 2 Sekolah Dasar Negeri Srengseng Sawah 12 Pagi pada mata pelajaran matematika materi penjumlahan dan pengurangan bilangan sampai 500melalui metode diskusi menggunakan media stik es krim.

\section{Manfaat hasil Penelitian}

Adapun manfaat dalam penelitian tindakan kelas (action research) ini adalah:

\section{Peserta didik :}

a. Peserta didik menjadi lebih aktif dan kreatif dalam belajar Matematika.

b. Motivasi untuk meningkatkan pemahaman mata pelajaran matematika pada peserta didik bertambah.

c. Menciptakan rasa senang belajar matematika pada peserta didik selama pelajaran berlangsung.

d. Dapat meningkatkan hasil belajar peserta didik.

e. Peserta didik lebih mengerti dan memahami tentang penggunaan alat peraga stik es krim dalam penjumlahan dan pengurangan dengan teknik menyimpan dan meminjam.

\section{Bagi guru}

a. Memperbaiki proses belajar mengajar dalam pelajaran matematika di sekolah dasar.

b. Mengembangkan kualitas dan wawasan guru dalam mengajarkan pelajaran matematika di sekolah dasar.

c. Sebagai acuan untuk meningkatkan kemampuan guru.

d. Memberikan alterntif kegiatan pembelajaran matematika.

\section{Bagi Sekolah}

a. Meningkatkan Mutu pendidikan di sekolah

b. Memaksimalkan Peranan dan tanggung jawab sekolah dalam membekali peserta didiknya dengan pengetahuan dan kemampuan pelajaran matematika.

c. Sebagai sumbangan kepada pihak sekolah maupun sekolah lainnya dalam rangka perbaikan proses pembelajaran matematika.

d. Sebagai acuan pemilihan alat peraga/media dalam pembelajaran matematika agar hasil belajar peserta didik tidak rendah. 


\section{KAJIAN PUSTAKA}

\section{A. Hasil Belajar Matematika}

\section{Hasil Belajar}

\section{a. Pengertian Hasil Belajar}

Untuk memahami pengertian dari hasil belajar akan peneliti awali dengan mengemukakan beberapa pendapat para ahli definisi tentang belajar. Ada beberapa pendapat para ahli tentang definisi belajar. Cronbach, Harold Spears dan Geoch dalam Sardiman A.M (2005:20) menyatakan definisi belajar adalah sebagai berikut :

1. Cronbach memberikan definisi :

"Learning is shown by a change in behavior as a result of experience". Artinya dalam bahasa Indonesia "Belajar adalah memperlihatkan perubahan dalam perilaku sebagai hasil dari pengalaman".

2. Harold Spears memberikan definisi :

"Learning is to observe, to read, to initiate, to try something themselves, to listen, to follow direction". Artinya dalam bahasa Indonesia "Belajar adalah mengamati, membaca, berinisiasi, mencoba sesuatu sendiri, mendengarkan, mengikuti petunjuk/arahan".

3. Geoch, memberikan definisi :

"Learning is a change in performance as a result of practice". Artinya dalam bahasa Indonesia "Belajar adalah perubahan dalam penampilan sebagai hasil praktek.

Dari pendapat para ahli diatas dapat disimpulkan bahwa belajar merupakan suatu aktivitas yang dilakukan seseorang atau sekelompok orang dengan sengaja dan dalam keadaan sadar untuk memperoleh atau mendapatkan suatu konsep, pemahaman, atau pengetahuan baru sehingga memungkinkan terjadinya perubahan pada perilaku perilaku seseorang yang relatif tetap baik dalam berpikir, merasa, maupun dalam bertindak.

Sedangkan definisi dari hasil adalah sesuatu yang telah dikerjakan atau diciptakan baik secara individu atau kelompok. Dalam suatu proses aktivitas seseorang pasti menginginkan suatu hasil, begitu pula pada proses belajar mengajar yang dilakukan di sekolah. Setiap pembelajaran memiliki tujuan yang diharapkan atau mengharapkan hasil yang dicapai sesuai dengan yang telah dirancang.Belajar dan mengajar merupakan konsep yang tidak bisa dipisahkan. 
Belajar merujuk pada apa yang harus dilakukan seseorang sebagai subjek dalam belajar. Sedangkan mengajar merujuk pada apa yang seharusnya dilakukan seorang guru sebagai pengajar.Dari proses belajar diharapkan memperoleh hasil yang baik sesuai dengan tujuan instruksional khusus yang ditetapkan sebelum proses belajar berlangsung. Salah satu cara yang dapat dilakukan untuk mengetahui tingkat keberhasilan belajar adalah dengan menggunakan tes. Evaluasi atau tes digunakan untuk menilai hasil belajar yang dicapai dalam materi pelajaran yang diberikan guru di sekolah.

Umumnya hasil belajar dalam sekolah berbentuk pemberian nilai (angka) dari guru kepada peserta didik sebagai indikasi sejauh mana peserta didik telah menguasai materi pelajaran yang disampaikan oleh guru, biasanya hasil belajar ini dinyatakan dengan angka, huruf, atau kalimat dan terdapat dalam periode tertentu. Prosedur evaluasi pembelajaran harus sesuai dengan prosedur pembelajaran sehingga dapat menilai proses dan hasil belajarnya.

Menurut Dimyanti(2013:3) "Hasil belajar merupakan hasil dari suatu interaksi tindak belajar dan tindak mengajar”. Sedangkan menurut Nawawi (2013:5) "Hasil belajar diartikan sebagai tingkat keberhasilan siswa dalam mempelajari materi pelajaran di sekolah yang dinyatakan dalam skor yang diperoleh dari hasil evaluasi atau tes mengenal sejumlah materi pelajaran tertentu".

Hasil belajar menurut Kamus Besar Bahasa Indonesia (2008 : 1101) adalah berusaha memperoleh kepandaian atau ilmu penguasaan pengetahuan atau keterampilan yang dikembangkan oleh mata pelajaran, lazimnya ditunjukkan dengan nilai tes atau angka nilai yang diberikan oleh guru." Dalam hal ini hasil belajar merupakan suatu kemajuan dalam perkembangan peserta didik setelah ia mengikuti kegiatan belajar dalam waktu tertentu. Seluruh pengetahuan, keterampilan, kecakapan dan perilaku individu terbentuk dan berkembang melalui proses belajar.

Dari penjabaran - penjabaran tersebut dapat disimpulkan bahwa hasil belajar merupakan suatu proses belajar mengajar yang ditandai dengan adanya perubahan tingkah laku, pengetahuan, keterampilan dan kemampuan yang dimiliki peserta didik itu sendiri setelah ia menerima serta melakukan aktivitas belajar dan adanya interaksi dari tindak belajar dan tindak mengajar. 


\section{b. Kriteria Ketuntasan Minimal (KKM)}

Kriteria atau nilai paling rendah yang menyatakan peserta didik berhasil mencapai ketuntasan dinamakan Kriteria ketuntasan minimal (KKM) yang merupakan acuan kriteria penilaian pada kurikulum berbasis kompetensi.

Kriteria ketuntasan minimal (KKM) harus ditetapkan sebelum awal tahun ajaran di mulai. Seberapa pun besarnya jumlah peserta didik yang melampaui batas ketuntasan minimal, tidak berpengaruh terhadap keputusan pendidik dalam menyatakan lulus dan tidak lulusnya peserta didik dalam mengikuti proses pembelajaran.

Kriteria ketuntasan minimal (KKM) ditetapkan berdasarkan hasil musyawarah guru mata pelajaran di satuan pendidikan atau beberapa satuan pendidikan yang memiliki karakteristik yang hampir sama. Pertimbangan pendidik secara akademis menjadi pertimbangan utama penetapan Kriteria ketuntasan minimal (KKM).

\section{Hakikat Mata Pelajaran Matematika}

\section{a. Pengertian Pembelajaran Matematika}

Matematika diartikan oleh Johnson dan Rising (Erman Suherman, 2003: 19) sebagai pola berpikir, pola mengorganisasi, pembuktian yang logik, bahasa yang menggunakan istilah yang didefinisikan dengan cermat, jelas, dan akurat. Menurut Erman Suherman (2003:253) matematika adalah disiplin ilmu tentang tata cara berfikir dan mengolah logika, baik secara kuantitatif maupun secara kualitatif. Menurut Johnson dan Myklebust yang dikutip olah Mulyono Abdurrahman (2002:252) matematika adalah bahasa simbiolis yang fungsi praktisnya untuk mengekspresikan hubunganhubungan kuantitatif dan keruangan sedangkan fungsi teoritisnya adalah untuk memudahkan berfikir.

Pembelajaran adalah suatu kondisi yang dengan sengaja diciptakan oleh guru guna membelajarkan peserta didik (Syaiful Bahri Djamarah, 2002: 43).Erman Suherman (2003: 8) mengartikan pembelajaran sebagai upaya penataan lingkungan yang memberi nuansa agar program belajar tumbuh dan berkembang secara optimal. Menurut Undang-Undang Sisdiknas tahun 2003 (Benny Susetyo, 2005: 167) pembelajaran adalah proses interaksi peserta didik dengan pendidik dan sumber belajar pada suatu lingkungan belajar. Peserta didik yang dimaksud adalah siswa dan pendidik adalah guru. Menurut Sugihartono (2007: 81), pembelajaran adalah suatu upaya yang dilakukan oleh guru untuk menyampaikan ilmu pengetahuan, mengorganisir, dan 
menciptakan sistem lingkungan dengan berbagai metode sehingga siswa dapat melakukan kegiatan belajar secara efektif dan efisien serta dengan hasil yang optimal.

Dari pengertian diatas dapat disimpulkan bahwa pembelajaran Matematika adalah suatu proses belajar mengajar yang dibangun oleh guru untuk mengembangkan kreativitas berpikir peserta didik yang dapat meningkatkan kemampuan berpikir peserta didik, serta dapat meningkatkan kemampuan mengkonstruksi pengetahuan baru sebagai upaya meningkatkan penguasaan yang baik terhadap materi matematika. Pembelajaran matematika merupakan suatu proses belajar mengajar yang mengandung dua jenis kegiatan yang tidak terpisahkan, kegiatan tersebut adalah belajar dan mengajar.

Dalam proses pembelajaran matematika, baik guru maupun peserta didik bersama-sama menjadi pelaku terlaksananya tujuan pembelajaran. Tujuan pembelajaran ini akan mencapai hasil yang maksimal apabila pembelajaran berjalan secara efektif. Pembelajaran yang efektif adalah pembelajaran yang mampu melibatkan seluruh peserta didik secara aktif.

\section{b. Tujuan Pembelajaran Matematika}

Secara umum, tujuan pembelajaran matematika adalah agar peserta didik mampu dan terampil menggunakan matematika. Menurut Depdiknas (2012:9), salah satu kompetensi atau kemampuan umun pembelajaran matematika, adalah Melakukan operasi hitung penjumlahan, pengurangan, perkalian, pembagian beserta operasi campurannya, termasuk yang melibatkan pecahan.

Secara khusus, tujuan pembelajaran matematika sebagaimana yang sudah disajikan oleh depdiknas, sebagai berikut:

1. Memahami konsep matematika, menjelaskan keterkaitan antar konsep, dan mengaplikasi konsep.

2. Menggunakan penalaran pada pola dan sifat, melakukan manipulasi matematika dalam generalisasi, menyusun bukti, atau menjelaskan gagasan dan pertanyaan matematika.

3. Memecahkan masalah yang meliputi kemampuan memahami masalah, merancang model matematika, menyelesaiksan model, dan menafsirkan solusi yang diperoleh.

4. Mengkomunikasikan gagasan dan simbol, tabel, diagram, atau media lain untuk menjelaskan keadaan atau masalah.

5. Memiliki sikap menghargai penggunaan matematika dalam kehidupan sehari-hari.

\section{Metode Pembelajaran Matematika}

Metode pembelajaran adalah aktivitas guru dalam merencanakan suatu strategi untuk mencapai tujuan umum seperti penguasaan konsep - konsep, prinsip - prinsip, dan keterampilan.Salah satunya adalah mengajar peserta didik bagaimana menyelesaikan masalah dan menumbuhkan sikap menyukai matematika yang merupakan kedua bentuk 
kegiatan yang berpusat kepada penalaran dan peserta didik.Di dalam merencanakan suatu metode pembelajaran matematika sikap guru harus memperhatikan tidak hanya hakekat matematika tetapi juga psikologi. Hakekat matematika dan psikologi ini akan membantu guru menentukan pengorganisasian topik - topik matematika dan pengalaman belajar, bagaimana cara penyampaiannya, bagaimana memberikan motivasi dan pengulangan pengulangan agar lebih mantap kepada peserta didik.

Supaya pembelajaran dapat menjadi lebih menyenangkan ada beberapa metode belajar yang efektif untuk proses belajar mengajar, khususnya dalam pengajaran matematika. Pada umumnya, metode yang digunakan dalam pengajaran bukan hanya menerapkan satu metode saja, tetapi gabungan dari beberapa metode. Misalnya metode ceramah dilaksanakan dengan metode diskusi dan tanya jawab. Hal tersebut dilakukan supaya pembelajaran menjadi lebih hidup dan peserta didik menjadi lebih berani dalam menyampaikan pendapat atau pun bertanya. Adapun metode - metode yang biasa digunakan dalam pembelajaran matematika adalah :

1. Ceramah

Ceramah adalah komunikasi satu arah dan merupakan suatu cara penyampaian informasi secara lisan dari guru kepada peserta didik. Pada metode ini, peran guru sangat dominan.

2. Ekspositori

Metode ekspositori hampir sama dengan metode ceramah. Yang membedakan adalah guru tidak terlalu dominan dan peserta didik mulai memiliki peran dalam proses belajar mengajar.

3. Demonstrasi

Metode demonstrasi hampir sama dengan metode ekspositori Pada metode ini biasanya menggunakan media atau alat peraga. Peserta didik juga akan banyak dilibatkan. Bukan hanya guru yang harus pandai mendemonstrasikan alat peraga, tetapi peserta didik juga harus bisa. Ketika peserta didik ikut mencoba mendemonstrasikan alat peraga, maka peserta didik akan mempunyai banyak pengalaman dan biasanya dapat menambah motivasi dalam belajar.

4. Latihan Hafal (drill) dan Latihan Praktek (practice)

Latihan hafal adalah kegiatan yang dilakukan melalui hafalan untuk menjawab beberapa soal secara lisan.Sedangkan latihan praktek adalah kegiatan mengingat langkah-langkah atau prosedur suatu konsep untuk mencapai jawaban yang benar.

5. Tanya Jawab

Pada metode ini pembelajaran akan lebih hidup dibandingkan dengan metode sebelumnya. Dalam pembelajaran ini, peserta didik lebih aktif karena terjadi kegiatan tanya jawab antara peserta didik dengan guru. 
6. Diskusi

Metode diskusi merupakan metode banyak arah.Diskusi bisa terjadi antara peserta didik kepada guru, guru kepada peserta didik dan peserta didik dengan peserta didik.Banyak keunggulan yang didapat dari metode ini, diantaranya melatih siswa untuk berani berpendapat dan mengajukan pertanyaan.Selain itu juga dapat melatih sikap bermusyawarah antar peserta didik.

7. Permainan

Dalam metode permainan, peserta didik dapat lebih santai dalam mempelajari konsep matematika tanpa ada beban.Metode ini sangat bagus terutama dalam membangkitkan minat dan motivasi peserta didik dalam belajar matematika. Suasana belajarpun akan terasa lebih santai dan tidak tegang.

8. Laboratorium

Metode laboratorium adalah metode yang memberikan kesempatan kepada peserta didik untuk memahami suatu objek langsung matematika dengan jalan mengkaji, menganalisis, menemukan secara induktif melalui inkuiri, merumuskan dan mengetes hipotesis dan membuat kesimpulan dari benda-benda konkrit.

\section{Media Atau Alat Peraga Pembelajaran Matematika}

Alat peraga adalah segala sesuatu berbentuk benda atau gambar yang dapat digunakan untuk menyatakan pesan merangsang pikiran, perasaan dan perhatian dan kemauan peserta didik sehingga dapat mendorong proses belajar (Sundayana 2014:07). Sedangkan Menurut Pramundjono (2014:07) alat peraga diartikan dengan benda kokret yang dibuat, dihimpun atau disusun secara sengaja digunakan untuk membantu menanamkan atau menggembangkan konsep matematika. Alat peraga adalah suatu alat yang dapat diserap oleh mata dan telinga dengan tujuan membantu guru agar proses belajar mengajar siswa lebih efektif dan efisien. Alat peraga dalam mengajar memegang peranan penting sebagai alat bantu untuk menciptakan proses belajar mengajar yang efektif.

Proses belajar mengajar ditandai dengan adanya beberapa unsur antara lain tujuan, bahan, metode dan alat, serta evaluasi. Unsur metode dan alat merupakan unsur yang tidak bisa dilepaskan dari unsur lainnya yang berfungsi sebagai cara atau teknik untuk mengantarkan yang berfungsi sebagai bahan pelajaran agar sampai ketujuan yakni peserta didik. Dalam pencapain tersebut, peranan alat peraga memegang peranan yang penting sebab dengan adanya alat peraga ini bahan dengan mudah dapat dipahami oleh peserta didik. Adapun beberapa contoh alat peraga adalah buku paket, papan tulis dan spidol, anggota tubuh (jari tangan), stik es krim dan lain - lain. Stik es krim adalah salah satu alat peraga yang peneliti gunakan untuk pembelajaran matematika materi penjumlahan dan pengurangan bilangan sampai 500 melalui metode diskusi. 


\section{a. Pengertian Stik Es Krim}

Stik es krim adalah suatu benda berbentuk stik kayu ukuran $12 \mathrm{~cm}$ x $1 \mathrm{~cm}$ x 1,8 $2 \mathrm{~mm}$ ini biasanya berbahan dari kayu sengon (albasia) dan pinus yang telah melalui proses oven dan sanding (bahan halus). Dengan melalui tahapan proses pemilihan bahan baku yang tepat serta proses produksi yang aman dan higienis dengan menggunakan mesin stik es krim yang modern, sehingga stik es krim tidak mengandung zat-zat yang berbahaya seperti hidrogen, peroksida, boraks, formalin, pemutih, pengawet, anti jamur dan lainnya. Bahan ini sangat aman digunakan untuk bahan makanan.Karena bahannya aman maka peneliti memilih alat peraga stik es krim sebagai media atau alat peraga untuk pembelajaran matematika materi penjumlahan dan pengurangan bilangan sampai 500 melalui metode diskusi.

\section{b. Fungsi Alat Peraga Stik Es Krim}

Ada beberapa fungsi alat peraga stik es krim dalam pelajaran matematika, menurut Arsyat (2007:25) antara lain adalah:

1. Dengan adanya alat peraga, anak-anak akan lebih banyak mengikuti pelajaran dengan gembira, sehingga minatnya dalam mempelajari matematika semakin besar. Anak akan senang, terangsang, tertarik dan bersikap positif terhadap pengajaran matematika apalagi dibantu dengan warna - warna dari stik es krim yang dibuat dengan warna - warna yang menarik buat anak.

2. Dengan disediakannya alat peraga stik es krim pada pembelajaran matematika dalam bentuk diskusi, maka peserta didik pada tingkat-tingkat yang lebih rendah akan lebih mudah memahami dan mengerti dengan bertukar pendapat dengan teman.

3. Alat peraga stik es krim dapat membantu daya tarik peserta didik, karena bisa membedakan antara ratusan, puluhan dan satuan. Sehingga dengan memudahkan proses praktek menghitung penjumlahan dan pengurangan dengan menggunakan media atau alat peraga.

4. Peserta didik akan menyadari adanya hubungan antara pengajaran dengan bendabenda kongkret yang ada di sekitar.

5. Konsep-konsep abstrak yang tersajikan dalam bentuk konkret, yaitu dalam bentuk model matematika dapat dijadikan objek penelitian dan dapat pula dijadikan alat untuk penelitian ide-ide baru dan relasi-relasi baru.

Berdasarkan penjelasan tersebut, maka penggunaan alat peraga stik es krim untuk pembelajaran matematika materi penjumlahan dan pengurangan bilangan sampai 500, akan sangat membantu keefektifan proses pembelajaran dan penyampaian pesan dan isi pelajaran. Selain membangkitkan motivasi dan minat belajar, alat peraga juga dapat membantu peserta didik meningkatkan pemahaman, penyajian data dengan 
menarik dan terpercaya, memudahkan penafsiran data, dan memudahkan informasi yang disampaikan.

\section{c. Tujuan Alat Peraga Stik Es Krim}

Dalam proses belajar mengajar matematika materi penjumlahan dan pengurangan bilangan sampai 500 alat peraga stik es krim dipergunakan dengan tujuan membantu guru agar proses belajar peserta didik lebih efektif dan efisien.

Adapun tujuan dari alat peraga dalam penelitian ini adalah:

1. Memperkenalkan, membentuk, memperkaya, serta memperjelas materi penjumlahan dan pengurangan bilangan sampai 500 .

2. Mengembangkan sikap aktif berdiskusi peserta didik.

3. Mendorong keaktivitasan peserta didik.

\section{d. Kelebihan Dan Kekurangan Alat Peraga Stik Es Krim}

Setiap media atau alat peraga pasti mempunyai kelebihan dan kekurangan. Adapun kelebihan dan kekurangan penggunaan alat peraga stik es krim dalam pengajaran materi penjulahan dan pengurangan bilangan antara lain adalah :

1. Kelebihan penggunaan alat peraga stik es krim

a) Alat peraga stik es krim sangat mudah di dapat dan bahannya pun cukup sederhana dan aman bagi peserta didik.

b) Menumbuhkan minat belajar matematika bagi peserta didik karena pelajaran menjadi lebih menyenangkan dengan melihat warna dari alat peraga stik es krim.

c) Memperjelas makna pembelajaran matematika materi penjumlahan dan pengurangan bilangan sampai 500 melalui metode diskusi sehingga peserta didik lebih mudah memahaminya

d) Metode mengajar akan lebih bervariasi sehingga peserta didik tidak akan mudah bosan.

e) Membuat peserta didik lebih aktif melakukan kegiatan belajar seperti mengamati, melakukan, mendemonstrasikan dan lain sebagainya.

2. Kekurangan alat peraga stik es krim yaitu:

a) Alat peraga stik es krim tidak tahan lama mungkin sampai 4 atau 5 bulan setelah di cat pewarna.

b) Mengajar dengan memakai alat peraga lebih banyak menunjuk guru untuk berpikir kreatif.

c) Banyak waktu yang diperlukan untuk persiapan alat peraga stik es krim . 
d) Perlu kesediaan berkorban pikiran untuk guru bagaimana supaya lebih menarik perhatian peserta didik.

\section{e. Langkah - langkah Penggunaan Alat Peraga Stik Es Krim}

Langkah-langkah Penggunaan Alat Peraga Stik Es Krim dalam Pembelajaran adalah sebagai berikut:

1. Guru membagi peserta didik dalam 5 kelompok sebagai grup diskusi.

2. Guru membagikan media atau alat peraga kemasing - masing kelompok.

3. Guru memberikan penjelasan mengenai alat peraga yang digunakan. Bilangan ratusan menggunakan stik es krim berwarna merah, untuk nilai puluhan menggunakan stik es krim berwarna kuning dan yang satuan menggunakan stik es krim berwarna hijau, bilangan yang akan dihitung 1 sampai 500 .

4. Guru menuliskan contoh soal penjumlahan dan pengurangan bilangan sampai 500 dipapan tulis untuk latihan menggunakan stik es krim.

5. Peserta didik menghitung stik es krim yang sudah di beri warna sesuai dengan angkanya untuk menghitung penjumlahan dan pengurangan dengan teknik menyimpan dan meminjam.

6. Peserta didik menulis di buku jumlah dari hasil tugas yang diberikan guru.

Peserta didik melakukan kegiatan tersebut secara berulang, dengan catatan stik es krim tidak berantakan dan hasil dari cara menghitung itu ditulis sesuai cara menghitungnya yang bersusun panjang ataupun pendek sesuai perintah dari guru. Dalam penelitian ini peneliti melakukan operasi hitung penjumlahan dan pengurangan bilangan sampai 500 berdasarkan langkah-langkah tersebut, sehingga peserta didik bermain sambil belajar.

\section{PELAKSANAAN PENELITIAN PERBAIKAN PEMBELAJARAN}

\section{A. Subjek, Tempat, Waktu Penelitian dan Pihak yang Membantu}

\section{Subjek dan Tempat Penelitian}

Subjek Penelitian tindakan kelas dipilih dan dilaksanakan berdasarkan tempat penulis bertugas, dengan jumlah 31 orang peserta didik kelas II SDN Srengseng Sawah 12 Pagi, Kecamatan Jagakarsa, Kota Jakarta Selatan. Tempat yang digunakan berlokasi di Jl Gardu Rt.011/002 Kelurahan Srengseng Sawah, Kecamatan Jagakarsa, Kota Jakarta Selatan.

\section{Waktu Penelitian}

Pelaksanaan penelitian perbaikan pembelajaran pada pelajaran matematika diawali dari perencanaan hingga sampai pada laporan hasil penelitian.Waktu penelitian tindakan kelas berlangsung mulai dari tanggal 18 Juli s/d 05 Agustus 2018. 
Pelaksanaan penelitian tindakan kelas pada pelajaran matematika diawali dengan prasiklus pada hari rabu tanggal 20 Juli 2018 yang menjadi sumber permasalahan yang ditemui. Kemudian dilanjutkan perbaikan pembelajaran siklus 1 pada hari senin tanggal 25 Juli 2018 yang merupakan perbaikan pembelajaran tahap pertama setelah prasiklus. Selanjutnya siklus 2 hari Selasa tanggal 02 Agustus 2018 sebagai perbaikan pembelajaran yang hasilnya diharapkan akan lebih baik. Berikut adalah tabel Jadwal Pelaksanaan Perbaikan Pembelajaran

\section{B. Desain Prosedur Perbaikan Pembelajaran}

Agar peneliti memperoleh hasil yang diharapkan dan kegiatan penelitian ini terarah dengan baik, maka peneliti terlebih dahulu melakukan persiapan penelitian. Persiapan penelitian yang dilakukan meliputi hal-hal sebagai berikut:

1. Mengobservasi hal-hal yang akan diteliti, menyiapkan sarana dan prasarana yang diperlukan.

2. Menentukan kelas yang akan diteliti yaitu kelas II SDN Srengseng Sawah 12 Pagi, Kota Jakarta Selatan.Menentukan mata pelajaran yang akan dijadikan objek penelitian yaitu pelajaran matematika.

3. Menentukan materi pelajaran yaitu penjumlahan dan pengurangan bilangan sampai 500 .

4. Merancang penelitian tindakan kelas dengan tahapan perencanaan tindakan, pelaksanaan, observasi, dan evaluasi.

Desain prosedur perbaikan yang peneliti lakukan terdiri dari beberapa siklus yang setiap siklusnya terdiri dari empat tahapan, yaitu : tahap persiapan sebagai perencanaan, pelaksanaan, pengamatan atau obsesrvasi dan tahap refleksi.

Setiap daur atau siklus dalam penelitian ini memiliki langkah atau tahapan yang sama. Prasiklus dilakukan sebagai usaha mengetahui permasalahan yang menjadi dari latar belakang penelitian tindakan kelas dan dilanjutkan lagi dengan kegiatan siklus 1 yang merupakan perbaikan dari prasiklus dan diakhiri pada siklus ke 2 sebagai perbaikan dari siklus 1 .

Setelah itu peneliti melakukan diskusi dan mempelajari pengamatan yang dilakukan oleh teman sejawat dan mempersiapkan segala yang dibutuhkan dalam pelaksanaan perbaikan pembelajaran sebagai langkah dalam penelitian yang telah dideskripsikan. 
Dalam Penelitian ini dilaksanakan dua siklus yang masing-masing melalui 4 tahapan yaitu tahap perencanaan, pelaksanaan, pengamatan dan refleksi. Adapun pelaksanaan penelitian tersebut dideskripsikan sebagai berikut:

\section{Siklus 1}

\section{a. Persiapan}

1. Perencanaan pelaksanaan pembelajaran yang akan dilaksanakan pada hari Senin tanggal 25 Juli 2018.

2. Guru menyusunan Rencana pelaksanaan pembelajaran matematika dengan materi penjumlahan dan pengurangan bilangan sampai 500.

3. Penyusunan metode pembelajaran berupa ceramah, diskusi dan tanya jawab, Penugasan.

4. Persiapan sumber belajar dan bahan ajar berupa Buku paket dan LKS Matematika kelas II SD Pengarang Drs. Sutono. Mpd, dkk. Penerbit PT. Sarana Panca Karya Nusa.

5. Penyusunan alat evaluasi pembelajaran atau lembar kerja peserta didik.

\section{b. Pelaksanaan}

1. kegiatan awal ( \pm 10 menit)

a. Apresepsi/ Motivasi :

- Peserta didik menjawab salam dari guru ( Religi )

- Peserta didik dipimpin ketua kelas untuk berdoa ( religi )

- Absensi

- Guru mempersiapkan materi ajar dan model alat peraga.

- Guru memberikan motivasi belajar kepada para peserta didik melalui "tepuk semangat".

- Mengkondisikan peserta didik dengan cara memotivasi dan membawa perhatian peserta didik agar tertuju pada materi pembelajaran dengan mengajukan beberapa pertanyaan yang mengacu pada materi yang akan diajarkan (rasa ingin tahu).

- Menugaskan peserta didik untuk membuat kelompok yang masing masing kelompok berjumlah 6 orang.

- Guru menyampaikan materi yang akan dipelajari yaitu penjumlahan dan pengurangan bilangan sampai 500 .

2. Kegiatan Inti ( \pm 15 menit $)$ 
a. Eksplorasi

- Guru menjelaskan tentang materi penjumlahan dan pengurangan.

- Guru memberikan contoh soal penjumlahan dengan teknik menyimpan dan tanpa menyimpan.

- Guru memberikan contoh soal pengurangan dengan teknik meminjam dan tanpa meminjam.

- Peserta didik memperhatikan penjelasan guru.

b. Elaborasi

- Guru memberikan pertanyaan tentang materi pelajaran.

- Peserta didik menjawab pertanyaan yang diberikan oleh guru.

- Guru memberikan soal - soal latihan.

- Peserta didik menyelesaikan soal yang diberikan guru.

- Guru melihat atau berkeliling ketiap kelompok peserta didik untuk melihat proses pengerjaan soal oleh peserta didik.

- Guru memeriksa hasil pekerjaan peserta didik

c. Konfirmasi

- Guru bertanya jawab tentang hal - hal yang belum diketahui peserta didik.

- Guru memberikan penguatan dan motivasi.

3. Kegiatan Akhir $( \pm 10$ menit $)$

- Dengan bimbingan guru memberikan kesimpulan dari materi yang disampaikan.

- Guru memberikan tugas PR.

- Berdoa.

- Salam.

\section{d. Pengamatan}

Berdasarkan pengamatan dan observasi saat guru mengajar, yang menjadi permasalahan dalam pembelajaran tersebut adalah:

1. Peserta didik kurang termotivasi dalam pembelajaran.

2. Nilai rata - rata kelas yang diperoleh 75,48 memenuhi KKM yaitu 70,00 namun belum maksimal dan hasil pengamatan menunjukkan bahwa hanya 10 orang $(30 \%)$ peserta didik yang mampu menjawab dengan benar pertanyaan yang guru berikan secara langsung. 
3. Tanggung jawab peserta didik akan tugas masih rendah, saat diberikan tugas belum dilaksanakan dengan optimal.

4. Media yang digunakan dalam pembelajaran belum maksimal.

5. Keterlibatan peserta didik dalam kegiatan pembelajaran masih kurang.

\section{e. Refleksi}

Dari pelaksanaan pembelajaran siklus 1, ditemukan kekuatan dan kelemahan dalam tindakan perbaikan pembelajaran diantaranya:

\section{Kekuatan}
a) Pembelajaran lebih efektif dengan metode diskusi.
b) Guru sudah melibatkan peserta didik dalam pembelajaran.
c) Peserta didik mulai antusias terhadap media yang digunakan.
d) Pemahaman materi oleh peserta didik sedikit lebih baik.

\section{Kelemahan}

a) Aktiftas peserta didik belum semua terlibat.

b) Belum semua peserta didik mengerti dengan tugasnya.

c) Ruang kelas kurang kondusif karena masih ada anak yang sibuk dengan mengobrol.

d) Pembelajarn masih didominasi peserta didik yang aktif saja.

e) Perolehan hasil rerata kelas sudah diatas KKM yaitu diperoleh nilai rata rata 75,48. Peserta didik mencapai KKM adalah 26 peserta didik (85\%) peserta didik. Sedangkan hasil pengamatan menunjukkan bahwa hanya sebanyak $10(30 \%)$ orang peserta didik mampu menjawab dengan benar pertanyaan yang guru berikan secara langsung.. Dengan perolehan nilai tersebut peneliti merasa penelitian perlu dilanjutkan ke siklus berikutnya yaitu siklus 2.

\section{Siklus 2}

\section{a. Persiapan}

1. Perencanaan pelaksanaan pembelajaran yang akan dilaksanakan pada hari, Selasa tanggal 02 Agustus 2018.

2. Guru menyusunan Rencana pelaksanaan pembelajaran matematika dengan materi penjumlahan dan pengurangan bilangan sampai 500.

3. Penyusunan metode pembelajaran berupa ceramah, diskusi dan tanya jawab, penugasan. 
4. Persiapan sumber belajar, bahan ajar dan media atau alat bantu pembelajaran berupa Buku paket, LKS Matematika kelas II SD Pengarang Drs. Sutono. Mpd, dkk. Penerbit PT. Sarana Panca Karya Nusa dan stik es krim berwarna.

5. Penyusunan alat evaluasi pembelajaran atau lembar kerja peserta didik.

\section{b. Pelaksanaan}

1) Kegiatan awal ( \pm 10 menit)

Apresepsi/ Motivasi :

- Peserta didik menjawab salam dari guru ( Religi )

- Peserta didik dipimpin ketua kelas untuk berdoa ( religi )

- Absensi

- Guru memberikan motivasi belajar kepada para peserta didik melalui "tepuk semangat".

- Mengkondisikan peserta didik dengan cara memotivasi dan membawa perhatian peserta didik agar tertuju pada materi pembelajaran dengan mengajukan beberapa pertanyaan yang mengacu pada materi yang akan diajarkan (rasa ingin tahu)

- Guru menugaskan peserta didik untuk membuat kelompok yang masing masing kelompok berjumlah 6 orang.

- Guru menyampaikan materi yang akan dipelajari yaitu penjumlahan dan pengurangan bilangan sampai 500 .

- Guru menjelaskan tujuan pembelajaran : Pada pertemuan kali ini kita akan belajar tentang penjumlahan dan pengurangan bilangan sampai 500 dengan menggunakan stik es krim.Setelah memahami pelajaran ini, diharapkan kalian dapat menjumlah dan mengurangi bilangan sampai dengan 500.

- Guru mengaitkan kegiatan topik dengan menyampaikan manfaat konsep tersebut dalam kegiatan sehari

2) Kegiatan inti $( \pm 15$ menit $)$

a). Eksplorasi

- Guru memberikan penjelasan tentang materi penjumlahan dan pengurangan.

- Guru memberikan penjelasan tentang penggunaan alat bantu atau media stik es krim dalam menyelesaikan tugas atau soal - soal matematika tentang penjumlahan dan pengurangan. 
- Stik es krim terbagi dalam tiga warna yaitu pink, kuning dan hijau.

- Tiap warna pada stik es krim mewakili nilai bilangan

Warna pink mewakili nilai bilangan ratusan

Warna kuning mewakili nilai bilangan puluhan

Warna hijau mewakili nilai bilangan satuan

- Peserta didik memperhatikan penjelasan guru.

- Guru memberikan contoh soal penjumlahan dan pengurangan dengan menggunakan media stik es krim.

- Peserta didik mengerjakan contoh soal dari guru tentang penjumlahan dan pengurangan dengan media stik es krim secara berkelompok dan guru menghampiri tiap kelompok untuk memberikan bimbingan.

b). Elaborasi

- Guru memerintahkan kepada peserta didik untuk membentuk 5 kelompok.

- Peserta didik membentuk kelompok sesuai pengaturan dari guru.

- Kelompok sudah terbentuk guru memberikan soal - soal latihan tentang materi penjumlahan dan pengurangan dengan menggunakan media stik es krim.

- Guru berkeliling ketiap kelompok untuk membimbing peserta didik dalam mengerjakan tugas.

- Peserta didik memberikan hasil pekerjaan kepada guru.

- Guru memeriksa hasil pekerjaan peserta didik

c. Konfirmasi

- Menugaskan salah satu peserta didik yang merupakan perwakilan tiap tiap kelompok untuk menceritakan materi yang baru diterima dari guru dan peserta didik yang lain mendengar sambil membuat catatan-catatan kecil, kemudian berganti peran. Begitu juga kelompok lainnya.

- Guru meminta perwakilan dari setiap kelompok untuk melaporkan hasil diskusi (keberanian).

- Peserta didik bersama guru membahas hasil diskusi (kejujuran).

- Peserta didik bersama guru menyimpulkan hasil diskusi.

3). Kegiatan Akhir ( \pm 10 menit) 
- Dengan bimbingan guru memberikan kesimpulan dari materi yang disampaikan.

- Guru memberikan tugas PR.

- Berdoa.

- Salam.

\section{d. Pengamatan}

Peneliti melakukan pengamatan terhadap aktivitas peserta didik dalam mengikuti perbaikan pembelajaran dengan metode diskusi.Hasil pengamatan ternyata ada perubahan yang sangat berbeda karena peserta didik menjadi aktif, antusias, dan mengerti dengan jelas materi yang dipelajari. Hal itu berpengaruh dari hasil belajar yang meningkat dari Siklus 1 (nilai rerata 75,48) ke Siklus 2 (nilai rerata 90,97). Hal ini dikarenakan beberapa faktor antara lain :

a. Guru sudah menggunakanmedia pembelajaran yang sesuai secara maksimal sehingga terciptanya suasana pembelajaran yang kondusif, dan menyenangkan bagi peserta didik.

b. Guru sudah menggunakan metode pembelajaran dan teknik pembelajaran yang bervariasi dan efektif.

c. Guru sudah menggunakan media pembelajaran dan teknik pembelajaran yang bervariasi dan efektif.

d. Guru sudah memberikan motivasi pada saat pembelajaran berlangsung sehingga peserta didik menjadi tertarik pada pelajaran matematika khususnya materi penjumlahan dan pengurangan bilangan sampai 500 .

e. Guru sudah mengadakan rewarddanumpan balik secara langsung selama pembelajaran, sehingga peserta didik lebih aktif.

\section{e. Refleksi}

Dalam melakukan refleksi perbaikan pembelajaran, penulis dan teman sejawat mencatat beberapa hal yang sangat berpengaruh pada penerapan metode diskusi dan demonstrasi melalui media stik es krimyaitu:

1. Dengan menggunakan metode diskusi dengan alat peraga stik es krimpeserta didik mendapatkan suasan baru, sehingga dapat menghindari kebosanan dalam proses pembelajaran.

2. Dengan metode diskusi, dapat membiasakan peserta didik untuk berkomunikasi aktif dalam bertukar pikiran dengan teman. 
3. Dengan metode diskusi peserta didik diajarkan untuk mandiri, dan memiliki rasa setia kawan yang tinggi.

4. Dengan metode diskusi dan alat peraga stik es krim pada perbaikan pembelajaran pada siklus 2 ini hasil nilai rata - rata peserta didik sebesar 90,97. Peserta didik yang tuntas dalam belajarnya sebanyak $30(97 \%)$. orang peserta didik. Sedangkan yang belum tuntas sebanyak 1 orang peserta didik atau 3\% Dari hasil pengamatan yang belum menjawab dengan benar pertanyaan guru sebanyak 3 orang dari 31 peserta didik atau dengan kata lain $9 \%$.

5. Dengan metode diskusi dan alat peraga stik es krim mendapatkan keuntungan peserta didik dapat menambah pengalaman dan kepercayaan diri, peserta didik Pada akhirnya kualitas dan hasil belajar semakin membaik sehingga tidak dilanjutkan dengan siklus berikutnya.

\section{Teknik Analisis Data}

Data yang telah dikumpulkan pada setiap kegiatan observasi dari pelaksanaan siklus penelitian dianalisis secara deskriptif dengan menggunakan teknik presentase untuk melihat kecenderungan yang terjadi dalam kegiatan pembelajaran mata pelajaran matematika.

Dalam pelaksanaan penelitian ini membutuhkan dua siklus perbaikan untuk mata pelajaran matematika. Pada proses perbaikan pembelajaran yang peneliti lakukan adalah melalui empat tahapan, yaitu perencanaan, pelaksanaan, pengamatan dan refleksi.

Langkah-langkah dalam teknik analisis data yang dilakukan adalah sebagai berikut:

1. Melaksanakan kegiatan pembelajaran, yang terdiri dari kegiatan prasiklus, siklus 1, dan siklus 2.

2. Mengumpulkan dan menganalisis nilai evaluasi pembelajaran dari tiap siklus dan mendiskripsikannya.

3. Menentukan tingkat keberhasilan dari hasil evaluasi yang ditempuh dalam proses pembelajaran.

4. Tes digunakan untuk mendapatkan data tentang hasil belajar peserta didik.

5. Observasi, yang digunakan untuk mengumpulkan data tentang perkembangan keaktifan peserta didik dalam proses kegiatan belajar mengajar dengan menggunakan metode diskusi. 
6. Diskusi dengan teman sejawat tentang keberhasilan dan kekurangan/kelemahan dalam pelaksanaan pembelajaran metode diskusi menggunakanalat peraga stik es krim dan merefleksikan hasil setiap siklus untuk perbaikan-perbaikan aktivitas dan praktek pembelajaran yang akan datang.

\section{HASIL PERBAIKAN DAN PEMBAHASAN}

\section{A. Deskripsi Hasil Penelitian Perbaikan Pembelajaran}

Pemaparan data hasil penelitian tindakan kelas yang telah dilaksanakan untuk mata pelajaran matematika di kelas II SDN Srengseng Sawah Kota Jakarta Selatan yang dibantu dengan supervisor dalam menemukan kelemahan guru dan peserta didik sehingga dapat memberikan masukan terhadap perbaikan pelaksanaan pembelajaran.

Selain melaksanakan observasi, peneliti juga melaksanakan refleksi pada proses belajar mengajar untuk menemukan langkah-langkah perbaikan pembelajaran. Dari hasil refleksi, ditemukan kekurangan peneliti dalam pembelajaran yang kurang tepatnya metode pembelajaran dan media pembelajaran yang digunakan, sehingga tidak sesuai dengan kebutuhan peserta didik.

Berdasarkan hasil refleksi tersebut, ada beberapa hal yang menjadi perhatian peneliti dan perlu dilakukan perbaikan pada proses pembelajaran berikutnya, yaitu :

1. Rendahnya hasil belajar peserta didik pada mata pelajaran matematika.

2. Kurangnya perhatian peserta didik dalam pelajaran matematika.

3. Peserta didik kurang menyukai materi yang disampaikan guru.

4. Peserta didik tidak berani menjawab pertanyaan guru dalam pembelajaran.

Peneliti juga membuat beberapa instrumen sebagai berikut :

1. Lembar evaluasi tiap-tiap siklus dengan menulis rerata kelas.

2. Instrumen pengamatan peserta didik yang dapat atau tidak dapat menjawab pertanyaan guru.

Berikut deskripsi data dari setiap kegiatan pembelajaran prasiklus, siklus 1, dan siklus 2 .

\section{Siklus 1}

Pada pembelajaran siklus I jumlah nilai keseluruahan adalah 2340 dengan nilai tertinggi yang dicapai peserta didik sebesar 100 dan nilai terendah 40 dengan nilai rerata 75,48. Peserta didik yang belum mencapai KKM adalah 5 orang dari 31 peserta didik atau $15 \%$ dan peserta didik yang telah mencapai ketuntasan sebanyak 26 orang 
atau sebesar $85 \%$. Sedangkan hasil pengamatan menunjukkan bahwa sebanyak 10 orang dari 31 peserta didik menjawab dengan benar atau sebesar 30\%, dan yang belum menjawab dengan benar sebanyak 21 orang dari 31 peserta didik atau dengan kata lain $70 \%$.

Dari hasil evaluasi belajar peserta didik yang dilakukan pada siklus I, nilai hasil rata - rata kelas yang diperoleh 75,48 sudah memenuhi KKM yaitu 70,00 namun belum maksimal dan hasil pengamatan menunjukkan bahwa hanya 10 orang (30\%) peserta didik yang mampu menjawab dengan benar pertanyaan yang guru berikan secara langsung. sehingga penulis merasa perlu melakukan perbaikan pembelajaran melalui kegiatan siklus II .

\section{Siklus 2}

Pada siklus II, perolehan jumlah nilai keseluruhan 2820 dengan perolehan nilai tertinggi 100 dan nilai terendah adalah 60. Rerata kelas diperoleh nilai 90,97. Peserta didik yang tuntas dalam belajarnya sebanyak 30 orang dari 31 peserta didik atau $97 \%$. Sedang yang belum tuntas sebanyak 1 orang dari 31 peserta didik atau $3 \%$ Dari hasil pengamatan yang dapat menjawab dengan benar pertanyaan guru sebanyak $28(91 \%)$ dan belum menjawab dengan benar pertanyaan guru $3(9 \%)$ peserta didik.

Dengan dilaksanakannya kegiatan siklus II yang merupakan perbaikan dari siklus-siklus sebelumnya, kemudian dilakukan evaluasi pembelajaran, ternyata nilai rerata peserta didik yang diperoleh mencapai 90.97 .

Setelah dilaksanakan perbaikan, kemudian dilakukan evaluasi pembelajaran, akhirnya dapat disajikan tabel rekapitulasi nilai hasil belajar dan pengamatan. Perbandingan perolehan nilai dari tiap-tiap siklus berbeda. Pada prasiklus nilai terendah40, siklus satu 40, siklus dua 60. Perolehan rerata prasiklus 65, siklus satu 75.48, siklus dua 90.97, begitu juga tingkat ketuntasan secara prosentase mengalami peningkatan. Prosentase pada prasiklus 50\%, siklus satu 85\%, siklus dua 97\%

\section{B. Pembahasan Hasil Penelitian Perbaikan Pembelajaran}

Pada kegiatan prasiklus dengan menggunakan metode ceramah dan media pembelajaran papan tulis kemudian dievaluasi perolehan nilai rerata peserta didik pada pembelajaran prasiklus jumlah nilai keseluruhan adalah 2015 dengan rincian nilai tertinggi 100 dan nilai terendah adalah 40 dengan nilai rerata kelas 65,00. Peserta didik yang tuntas dalam belajar hanya berjumlah 16 orang dari 31 peserta didik atau $50 \%$ dan yang belum mencapai ketuntasan belajar sebanyak 15 orang dari 31 peserta didik atau 
50\%. Sedangkan hasil pengamatan menunjukkan bahwa sebanyak 10 orang dari 31 peserta didik menjawab dengan benar atau sebesar 30\%, dan yang belum menjawab dengan benar sebanyak 21 orang dari 31 peserta didik atau dengan kata lain $70 \%$.

Pada pembelajaran prasiklus ini nilai rerata pembelajaran Matematika di bawah KKM, sehingga pretasi belajar masih rendah.Selanjutnya peserta didik kurang termotivasi dalam pembelajaran, peserta didik menjadi pasif dan tanggung jawab peserta didik terhadap tugas masih rendah. Penyebab faktor tersebut disebababkan karenaguru hanya menggunakan metode ceramah, sehingga tidak ada peserta didik terlibat aktif selama proses pembelajaran berlangsung. Hal ini menyebabkan para peserta didik merasa jenuh dan kurang termotivasi untuk mengikuti proses pembelajaran.

Pada pelaksanaan pembelajaran siklus 1 SDN Srengseng Sawah 12 pagi Kota Jakarta Selatan kelas 2 mata pelajaran matematika tema penjumlahan dan pengurangan bilangan sampai 500 dengan KKM 70 diperoleh jumlah nilai keseluruahan adalah 2340 dengan nilai tertinggi yang dicapai peserta didik sebesar 100 dan nilai terendah 40 dengan nilai rerata 75,48. Peserta didik yang belum mencapai KKM adalah 5 orang dari 31 peserta didik atau $15 \%$ dan peserta didik yang telah mencapai ketuntasan sebanyak 26 atau sebesar $85 \%$. Sedangkan hasil pengamatan menunjukkan bahwa sebanyak 10 orang dari 31 peserta didik menjawab dengan benar atau sebesar 30\%, dan yang belum menjawab dengan benar sebanyak 21 orang dari 31 peserta didik atau dengan kata lain $70 \%$.

Pada pembelajaran siklus I, peneliti menggunakan metode diskusi.Dilihat dari hasil belajar peserta didik, terjadi peningkatan nilai secara rerata sudah di atas KKM, namun masih belum maksimal karena secara pengamatan belum mencapai hasil yang diinginkan oleh peneliti.

Dari hasil pengamatan pembelajaran siklus 1 , peneliti mencatat beberapa masalah yaitu :

1. Peserta didik kurang termotivasi dalam pembelajaran.

2. Nilai rata - rata kelas yang diperoleh 75,48 memenuhi KKM yaitu 70,00 namun belum maksimal dan hasil pengamatan menunjukkan bahwa hanya 10 orang (30\%) peserta didik yang mampu menjawab dengan benar pertanyaan yang guru berikan secara langsung.

3. Tanggung jawab peserta didik akan tugas masih rendah, saat diberikan tugas belum dilaksanakan dengan optimal.

4. Media yang digunakan dalam pembelajaran belum maksimal. 
5. Keterlibatan peserta didik dalam kegiatan pembelajaran masih kurang.

Dengan demikian maka peneliti melakukan penelitian pada siklus 2. Untuk mengatasi permasalah di siklus 1 maka peneliti melakukan sebagai berikut :

1. Menggunakan media pembelajaran yang sesuai secara maksimal sehingga tidak terciptanya suasana pembelajaran yang kondusif, dan menyenangkan bagi peserta didik yaitu dengan menambahkan media stik es krim.

2. Mengoptimalkan metode diskusipada pembelajaran.

3. Teknik pembelajaran yang lebih bervariasi dan efektif dalam penggunaan alat peraga

4. Memberikan motivasi pada saat pembelajaran berlangsung sehingga peserta didik tertarik pada pelajaran matematika.

5. Mengadakan rewarddanumpan balik secara langsung selama pembelajaran, sehingga peserta didik menjadi aktif.

Pada saat perbaikan pembelajaran siklus II, peneliti mencoba memperbaiki kekurangan pada saat siklus 1 dengan menambahkan media stik es krim. Pada siklus 2 ini perolehan jumlah nilai keseluruhan 2820 dengan perolehan nilai tertinggi 100 dan nilai terendah adalah 60. Rerata kelas diperoleh nilai 90,97. Peserta didik yang tuntas dalam belajarnya sebanyak 30 orang dari 31 peserta didik atau 97\%. Sedang yang belum tuntas sebanyak 1 orang peserta didik atau 3\% Dari hasil pengamatan yang belum menjawab dengan benar pertanyaan guru sebanyak 28 orang dari 31 peserta didik atau dengan kata lain $91 \%$ dan yang tidak dapat menjawab pertanyaan guru dengan benar sebanyak 3 orang (9\%) peserta didik.

Dalam kegiatan pembelajaran pada siklus 2 ini peserta didik sangat berminat dan termotivasi untuk mengikuti pelajaran matematika.Ini di sebabkan karena tersedianya media yang digunakan yaitu stik es krim sesuai dengan materi yang diajarkan oleh guru. Sehingga selama proses belajar mengajar berlangsung, tercipta suasana pembelajaran yang menantang, merangsang dan menyenangkan bagi peserta didik.

Dengan demikian penggunaan metodediskusidanalat peraga stik es krimdapat meningkatkan hasil belajar peserta didikSDN Srengseng Sawah 12 pagi Kota Jakarta Selatan kelas 2 mata pelajaran matematika tema penjumlahan dan pengurangan bilangan sampai 500. Berdasarkan hasil pembelajaran pada siklus 2 tesebut peneliti tidak perlu melakukan perbaikan pembelajaran pada siklus berikutnya. 


\section{KESIMPULAN DAN SARAN TINDAK LANJUT}

\section{A. Simpulan}

Berdasarkan hasil Penelitian Tindakan Kelas (PTK) melalui aktivitas perbaikan pembelajaran yang telah dilaksanakan mulai dari prasiklus, siklus I sampai dengan siklus II pada mata pelajaran matematika, peneliti dapat menarik kesimpulan sebagai berikut :

1. Pada pembelajaran prasiklus diperoleh nilai rata-rata kelas 65,00 peserta didik yang tuntas dalam belajar hanya berjumlah $16(50 \%)$ peserta didik Sedangkan hasil pengamatan menunjukkan bahwa sebanyak 10 (30\%) didik dapat menjawab dengan benar. Pada siklus I nilai rata-rata 75,48. Peserta didik mencapai ketuntasan sebanyak 26 (85\%.) Sedangkan hasil pengamatan menunjukkan bahwa sebanyak 10 (30\%), dapat menjawab dengan benar. Pada pembelajaran siklus II, peneliti mencoba memperbaiki kekurang pada saat siklus 1 selain menggunakan metode diskusi juga menambahkan media stik es krim untuk penjumlahan dan pengurangan bilangan sampai 500. Pada siklus 2 diperoleh Rerata kelas 90,97. Peserta didik yang tuntas dalam belajarnya sebanyak 30 (97\%) peserta didik sedangkan hasil pengamatan yang dapat menjawab dengan benar pertanyaan guru sebanyak 28 (91\%). Dari hasil pembelajaran diatas dapat peneliti simpulkan bahwa peserta didik lebih aktif pada pembelajaran matematika tema penjumlahan dan pengurangan bilangan sampai 500 dengan menggunakan alat peraga stik es krim. Hal ini dapat terlihat dari meningkatnya aktifitas peserta didik dari siklus 1 ke siklus 2 yang peningkatannya sangat baik.

2. Dengan demikianpenerapan metode diskusi dan alat peraga stik es krim telah memberikan pengaruh yang sangat baik dengan meningkatkan hasil belajar dan motivasi peserta didik. Materi yang disampaikan dapat dimengerti peserta didik, tanggung jawab peserta didik terhadap tugas tinggi, serta membantu peserta didik untuk terlibat aktif di dalam kelas dan memudahkan guru dalam memberikan materi pembelajaran terhadap peserta didik.

\section{B. Saran Tindak Lanjut}

Berdasarkan pada kesimpulan diatas ada beberapa hal yang sebaiknya dilakukan guru dalam upaya meningkatkan hasil belajar peserta didik.

1. Motivasi yang kuat sangat dibutuhkan oleh seorang peserta didik sebelum melakukan pembelajaran. 
2. Bagi pendidik diharapkan dapat memilih alat peraga pembelajaran yang tepat sesuai materi yang diajarkan, karena penggunaan alat peraga yang tepat dapat meningkatkan hasil belajar peserta didik.

3. Suasana belajar yang aktif di dalam kelas akan memotivasi peserta didik dalam belajar.

4. Penggunaan metode diskusi dan media stik es krim dapat membantu peserta didik untuk lebih cepat memahami konsep materi pelajaran. Dalam hal ini dapat menjadi alternatif yang digunakan guru dalam mengajarkan pembelajaran matematika.

5. Memberikan kesempatan kepada peserta didik untuk lebih aktif di kelas, mengeluarkan pendapat untuk menumbuhkan rasa percaya diri serta keberanian anak dalam menjawab pertanyaan.

6. Tidak berhenti untuk selalu berinovasi mencari solusi dari setiap masalah pembelajaran yang terjadi saat kegiatan belajar mengajar berlangsung demi kemajuan generasi penerus bangsa.

\section{Referensi}

A.M, Sardiman. (2005). Interaksi Dan Motivasi Belajar Mengajar. Jakarta: Rajawali Press. Arikunto, Suharsimi. (2012).Penelitian Tindakan Kelas. Jakarta: Bumi Aksara.

Asrori, Muhammad. (2009).Penelitian Tindakan Kelas, Bandung: CV Wacana Prima.

Arsyat, A. (2007). Media Pembelajaran. Jakarta:Raja Grafindo Persada.

Depdiknas.(2008). Kamus Besar Bahasa Indonesia. Jakarta: Gramedia Pustaka.

Dimyati, dkk. (2013).Belajar Dan Pembelajaran.Jakarta: Rineka Cipta.

Djamarah.(2002). Psikologi Belajar.Jakarta: Rineka Cipta.

Badar, Dadan Samsul dan Sulfemi, Wahyu Bagja. (2014). Pengaruh Rasa Percaya Diri dan Motivasi Berprestasi Terhadap Kinerja di Kecamatan Ciampea Kabupaten Bogor. Edutecno. 10 (1), 1-10,

Fajartriani, Tia dan Sulfemi, Wahyu Bagja. (2014). Pengaruh Motivasi Kerja Guru dan Iklim Organisasi Terhadap Kinerja Guru SMA Negeri di Kecamatan Cigudeg. Edutecno. 8 (1), 17-26.

Sugihartono. (2007).Psikologi Pendidikan. Yogyakarta: UNY pres.

Suherman, Erman. (2003). Evaluasi Pembelajaran Matematika. Bandung:JICA UPI.

Supardi. (2012).Penelitian Tindakan Kelas, Jakarta: Bumi Aksara.

Susanto, Ahmad. (2013).Teori Belajar Dan Pembelajaran Disekolah Dasar. Jakarta: Kencana

Susetyo, Benny. (2005). Politik Pendidikan Penguasa. Yogyakarta: PT LKIS Pelangi Aksara. 
Sulfemi, Wahyu Bagja. (2013). Pengaruh Persepsi Siswa atas Kemampuan Pedagogik Guru dan Motivasi Belajar Siswa Terhadap Prestasi Belajar Ilmu Pengetahuan Sosial Siswa (Survei di SMK Swasta Kabupaten Bogor). Edutecno. 7 (2), 17-26.

Sulfemi, Wahyu Bagja. (2014). Pengaruh Motivasi dan Lingkungan Sekolah Terhadap Prestasi Belajar Sejarah Di SMA Negeri Leuwilang Kabupaten Bogor. Fascho : Kajian Pendidikan dan Sosial Kemasyarakatan 9 (2), 42-52

Sulfemi, Wahyu Bagja. (2015). Pengaruh Metode Pembelajaran Kontekstual dan Penggunaan Media Video Pendidikan Terhadap Hasil Belajar IPS. Edutecno 13 (2), 1-10

Sulfemi, Wahyu Bagja. (2018). Hubungan Persepsi Peserta Didik Tentang Kompetensi Guru Mata Pelajaran Sejarah dengan Hasil Belajar Mata Pelajaran Sejarah di Kelas X SMA Negeri 1 Pamijahan Kabupaten Bogor. Fascho, 5 (2), 52-70

Sulfemi, Wahyu Bagja. (2018). Hubungan antara Persepsi Guru pada Kepemimpian Kepala Sekolah dan Motivasi Guru dengan Kinerja guru dalam Proses Pembelajaran di SMA Negeri 1 Ciomas. Fascho : Kajian Pendidikan dan Sosial Kemasyarakatan, 5 (1), 36-55

Sulfemi, Wahyu Bagja. (2018). Perundang-Undangan Pendidikan. Bogor : Program Studi Administrasi Pendidikan STKIP Muhammadiyah Bogor.

Sulfemi, Wahyu Bagja dan Lestari, Ayu Hopilatul. (2017). Korelasi Kompetensi Pedagogik Guru dengan Prestasi Belajar Mata Pelajaran IPS Di SMP Muhammadiyah Pamijahan Kabupaten Bogor. Edutecno. 16 (1), 1-16

Sulfemi, Wahyu Bagja dan Abdul Qodir. (2017). Hubungan Kurikulum 2013 Dengan Motivasi Belajar Peserta Didik Di SMK Pelita Ciampea. Edutecno 17 (2), 1-8.

Sulfemi, Wahyu Bagja. (2017). Analisis Pengaruh Motivasi Dan Disiplin Terhadap Kinerja Guru (Studi Kasus di SMA Negeri 1 Pamijahan Kabupaten Kabupaten Bogor). Prosiding Seminar Nasonal STKIP Muhammadiyah Bogor. 1 (1), 342-357

Sulfemi, Wahyu Bagja dan Supriyadi, Dede. (2018). Pengaruh Kemampuan Pedagogik Guru dengan Hasil Belajar IPS. Edutecno 17 (1), 1-10.

Usman, Husaini. (2011). Manajemen Teori, Praktek, Dan Riset Pendidikan, Jakarta: Bumi Aksara.

Yusfiriadi, Yusfitriadi dan Sulfemi, Wahyu Bagja. (2012). Penyelewangan Dana Dalam Dunia Pendidikan. Fascho 1 (1), 1-9

Wardhani, IGAK. (2014).Penelitian Tindakan Kelas, Tangerang Selatan: Universitas Terbuka. 
